DE

M E D I C I N A

T R O P I C A L

$\mathrm{DE}$

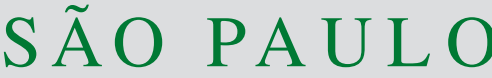

JOURNAL OF THE SÃO PAULO INSTITUTE OF TROPICAL MEDICINE

(1) Universidade Federal Rural do Rio de Janeiro, Instituto de Medicina Veterinária, Departamento de Epidemiologia e Saúde Pública, Seropédica, Rio de Janeiro, Brazil

(2)Universidade Federal Rural do Rio de Janeiro, Programa de Pós-Graduação em Ciências Veterinárias, Seropédica, Rio de Janeiro, Brazil

(3)Universidade Federal Rural do Rio de Janeiro, Programa de Pós-Graduação em Biologia Animal, Seropédica, Rio de Janeiro, Brazil

(4) Universidade Federal da Paraíba, Faculdade de Administração, João Pessoa, Paraíba, Brazil

Correspondence to: Argemiro Sanavria Universidade Federal Rural do Rio de Janeiro, Instituto de Medicina Veterinária, Departamento de Epidemiologia e Saúde Pública, BR 465, Km 7, CEP 23890-000, Seropédica, RJ, Brazil

Tel: +55 21 99974-0072

E-mail: argemirosanavria@yahoo.com.br

Received: 27 November 2016

Accepted: 17 May 2017

\section{Intelligent monitoring of Aedes aegypti in a rural area of Rio de Janeiro State, Brazil}

\author{
Argemiro Sanavria1, Claudia Bezerra da Silva², Érica Heleno Electo, Lidiane \\ Cristina Rocha Nogueira1, Sandra Maria Gomes Thomé ${ }^{1}$, Isabele da Costa \\ Angelo', Gilmar Ferreira Vita ${ }^{3}$, Talles Eduardo Cabral Sanavria ${ }^{4}$, Elisa \\ Domingues Padua1, Denise Glória Gaiotte ${ }^{1}$
}

\section{ABSTRACT}

The aim of this research was to monitor the presence of females of Aedes aegypti (Linnaeus, 1762) on the Seropédica municipality, Rio de Janeiro State, from 2010 to 2013. For this purpose, the Intelligent Dengue Monitoring (IM-Dengue) and Intelligent Virus Monitoring (IM-Virus) developed by Universidade Federal de Minas Gerais (Ecovec - Minas Gerais, Brazil), were used. IM-Dengue is a tool that allows achieving a weekly overview of $A$. aegypti infestation, while IM-Virus is another tool that allows detecting dengue virus directly from the mosquito, by Real Time-PCR. Both tools were developed for diagnosis in a prepathogenesis period of the disease, before infection occurrence. Traps were distributed in 19 locations inside the municipality and the bugs were collected weekly during the years of the research. As a result, the presence of 163 females of $A$. aegypti was recorded over the period; there was no circulation of the virus in the municipality. In one of the 19 study sites, a high degree of disease transmission risk was verified. The study concluded that the municipality, as a whole, showed no risk of disease transmission throughout the field research period.

KEYWORDS: Dengue. Virus. Epidemiology. Neglected diseases.

\section{INTRODUCTION}

Dengue is an acute febrile disease, whose etiologic agent is an arbovirus of the Flavivirus genus, belonging to the Flaviviridae Family. As vectors responsible for the transmission, it has mosquitos from the genus Aedes (Meigen, 1818), and more precisely in Americas, the Aedes aegypti (Linnaeus, 1762) species. There are currently four known different virus serotypes: DEN-1, DEN-2, DEN-3 e DEN-4 ${ }^{1,2}$.

Considered as a serious public health problem worldwide, especially in tropical and subtropical countries, in its severe form, it is a potentially lethal complication due to plasma leakage, fluid accumulation, breathing difficulties, drop in blood pressure, severe hemorrhage and organ damage ${ }^{3}$.

According to the World Health Organization, the disease incidence increased 30 times in the last five decades, with 390 million annual infections in more than 100 countries, meaning that nearly half of the world's population is at risk. An estimated number of 500,000 people suffering from the severe form of the disease requires hospitalization each year, and about $2.5 \%$ of them die $^{3}$.

In Brazil, until the month of May 2015, 1,021,004 cases were reported, with 378 deaths. Data report that 340 cities are at risk and 877 on alert. The Southeast region had the highest number of cases $(659,900 ; 64.63 \%)$, followed by the Northeast 
$(162,053 ; 15.87 \%)$, Central-West $(119,912 ; 11.74 \%)$, South $(54,473 ; 5.33 \%)$ and North $(24,666 ; 2.4 \%)$. The country allocated around 0.4 billion dollars to health surveillance actions, as well as additional resources, specific for each state and city ${ }^{4}$.

The Rio de Janeiro State, in the year of 2015, compared to the same period of the year of 2014 (first semester), showed an increase of $85.59 \%$ in the number of cases, with eight confirmed deaths. In the year of 2016, government agencies warned of the risk of epidemics in the cities of the metropolitan areas and in the state capital, due the circulation of serotypes DEN-2 and DEN-3 $3^{4,5}$.

In the Seropédica municipality, in the Rio de Janeiro State, 2,052 cases of dengue were recorded in the last ten years, from 2006 to 2015. In 2015, in the city, 92 cases of the disease were recorded. In 2016, until April, 41 cases were recorded, an increase by of $30.15 \%$, compared to the same period of $2015^{6}$. The municipality uses the methodology "Aedes aegypti Infestation Index Rapid Survey" (LIRAa), with its tools, to diagnose and establish strategies for epidemiological surveillance in all municipality area, including the campus of the Universidade Federal Rural do Rio de Janeiro.

The disease evolution, in its severe form, is hyperacute and can kill the patient within 24 hours after the first symptoms. There is no vaccine yet to prevent the disease, being the main strategies related to actions to control the vector and to early diagnosis of the disease. Therefore, establishing technologies that optimize these measures is crucial for more effective preventive actions and, consequently, to reduce the risk to which populations are exposed.

Thus, the aim of this research was to monitor the presence of the female A. aegypti in the Seropédica municipality, Rio de Janeiro State, in the period from 2010 to 2013, using the Intelligent Dengue Monitoring (IM-Dengue) and Intelligent Monitoring virus (IM-Virus) methodologies, as tools for early diagnosis of dengue.

\section{MATERIAL AND METHODS}

The research was conducted in the Seropédica municipality, metropolitan region of the Rio de Janeiro State, in the period from December 2010 to April 2013. The municipality has an area of 283.76 square kilometers, geographic coordinates Latitude $22.48^{\circ}$ South and Longitude $43.41^{\circ}$ West, and altitude of 33 meters above sea level ${ }^{7,8}$. The climate is semi-humid with abundant rains in the summer and dry winters, mean annual temperature of $24{ }^{\circ} \mathrm{C}$ and average rainfall of $1,250 \mathrm{~mm}^{1}$. The municipality has an ecological area of Atlantic Forest, with small forest fragments inside and around the municipality ${ }^{9}$.
The research collected mosquitoes weekly, during the mentioned period, and then sent the insects and the related information to the biotechnology and bioinformatics company Ecovec ${ }^{\circledR}$ (Minas Gerais, Brazil), to formulate a database and laboratory diagnosis. The following methods were used for this purpose: Intelligent Dengue Monitoring (IM-Dengue) and Intelligent Monitoring of Virus (IM-Virus), both developed by the Universidade Federal de Minas Gerais.

\section{Intelligent Dengue Monitoring (IM-Dengue)}

It is an adult vector monitoring service, which allows the researchers weekly to obtain a picture of the $A$. aegypti infestation. It consists of a kit with a dark color trap (MosquiTRAP), composed of a vessel with water, an attractive synthetic oviposition (AtrAedes), an cylindral adhesive card made for fixation of insects and a central lid with a funnel to avoid evasion; a mobile device (cell phone) to submit data; and a website that receives the data and made analytical information available to researchers in real time $\mathrm{e}^{10,11}$.

Traps were deployed in 19 strategic locations of the municipality, near edifications in order to cover areas with a greater traffic of people; each place was marked with a number of identification (ID), defined as follows: Inside the Universidade Federal Rural do Rio de Janeiro (UFRRJ): ID1 - Veterinary Institute, ID2 - Agronomy Institute, ID3 - Experimental Station for Parasitological Research W.O. Neitz, ID4 - Main Building, ID5 - Medical Center, ID6 - Geology Department, ID7 - Biology Institute, ID8 - Chemistry Institute, ID9 - Institute of Human and Social Sciences, ID10 - Guardhouse, ID16 - University Hall, ID17 - Biology Institute, ID18 - Student Accommodation, ID19 - Botanical Garden; outside the UFRRJ campus: ID11 Brazilian Agricultural Research Company (Animal's Health); ID12 - Technical College of Seropédica; ID13 - Animal Reproduction; ID14 - Pesagro-Rio (Organic Agriculture) and ID15 - Seropédica's Maternity Hospital (Figure 1). They were installed in visible places with water and plants, protected from sun and rain. Each collection point was georeferenced using the Global Positioning System (GPS), setting each latitude and longitude. The AtrAedes and the adhesive card were replaced every 45 to 60 days.

Each inspection consisted in counting the insects fixed to the card and distinguishing them according to their species and sex ${ }^{12,13}$. The inspection was done by UFRRJ's undergraduate students who were trained to identify the insects. To distinguish the sex of the genus Aedes, a differentiation of the male's feathery antennae and female's hairy antennae was carried out. The collected data were sent 


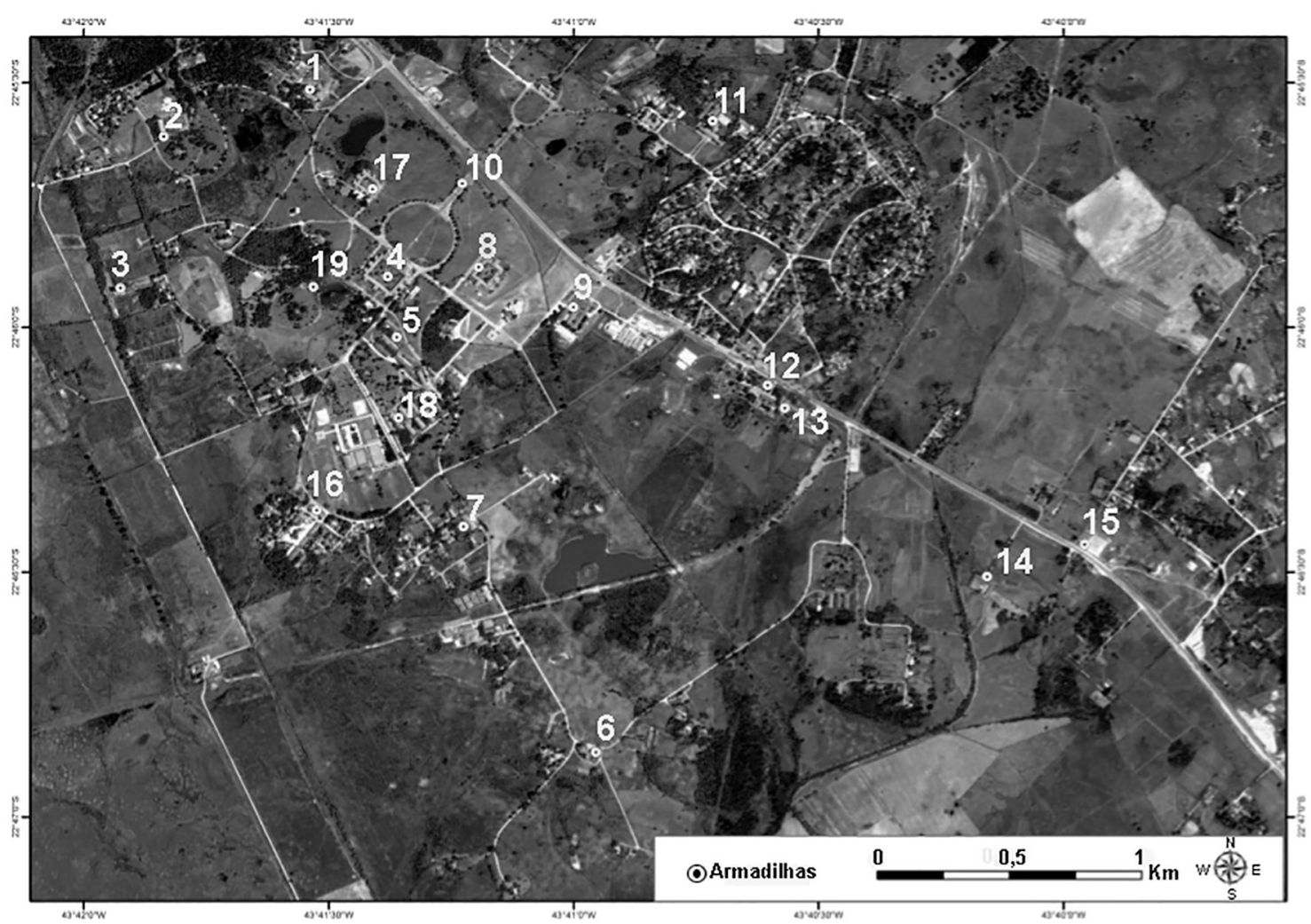

Figure 1 - Map showing the trap location and each trap ID number, Seropédica Municipality, Rio de Janeiro -State

in real time via a mobile device to the Ecovec website, to create the digital platform, chart and map projection.

To determine the disease's risk, the average index of the weekly collected females of A. aegypti (IMFA) was calculated by dividing the total number of females found by the total number of traps inspected during that week, ranking the levels in: satisfactory $(<0.15)$, moderate $(0.15$ to 0.30 ), alert ( 0.30 to 0.60$)$ and critical (>0.60), according to the Ecovec ${ }^{11}$.

The average female A. aegypti index (IMFA) was used for estimation of the disease transmission risk level for each trap location during all research period, from 2010 to 2013 , the total number of females found in a specific ID divided by the number of monitored traps in the same ID, over the period, was used.

\section{Intelligent Monitoring Virus (IM-Virus)}

IM-Virus allows the detection of the presence of viral infection in the collected mosquitoes. The trapped vectors of the genus Aedes are weekly collected and sent to the Ecovec laboratory. These vectors are analyzed by the RealTime-PCR technology, which is fast and has a high level of safety, and indicates the presence of RNA viral segments, specific of the Dengue Virus. The results are available as maps and tables ${ }^{11}$.
The mosquitoes were separated for analysis with the aid of a disposable wooden toothpick, to avoid contamination between insects of other traps. Then, to be transported, they were placed in a tube containing Guanidine Thiocyanate, and, finally, sent to Ecovec to search for the presence or absence of the Dengue Virus.

The research has also analyzed the association between temperature and rainfall with the number of females of A. aegytpi collected in the four seasons of the studied years, in order to know if the climate factors influenced a higher density of the vectors on campus. The average monthly rainfall data and temperature were obtained from the Instituto Nacional de Meteorologia, Estação Automática Rio de Janeiro - Seropédica ${ }^{14}$. The statistical analysis used was the Pearson linear correlation method provided by the SPSS Statistics 19.0 software $^{15}$, and the interpretation of correlation coefficients was performed according to Callegari-Jacques ${ }^{16}$.

\section{RESULTS}

The 2,197 IDs inspections were made during all the research period. The number of mosquitoes collected was 2,243, Aedes and Culex (Linnaeus, 1758) genus and A. aegypti e Aedes albopictus (Skuse, 1894) species. Culex was the predominant genus found with the number of 
1,302 mosquitoes. The number of collected females of $A$. aegypti was 163 , the year of 2011 was one with the highest appearance of the species (73) (Tables 1 and 2).

Regarding the epidemiological weeks with most appearance of the A. aegypti species in the selected IDs, the 50th week of the year of 2011 (from 11 to 17 December) was the week with the highest number of mosquitoes (nine), followed by week 13 of 2013 (from 24 to 30 march), with six mosquitoes. The weeks with appearance of the species in the given IDs were: from week 28 to 34 of 2011 (from July to August) and from week 19 to 30 of 2012 (from May to July) (Figure 2).

The IMFA, calculating for each epidemiologic week, evidenced that, in the years 2011 and 2013, the alert level was

Table 1 - Number of inspected traps, collected females of Aedes aegypti (IFMA), by deployed locations (ID), Seropédica municipality, RJ, from 2010 to 2013

\begin{tabular}{|c|c|c|c|c|}
\hline Years & IDs & $\begin{array}{l}\text { Number } \\
\text { of traps } \\
\text { inspected }\end{array}$ & $\begin{array}{c}\text { Number of } \\
\text { A. aegypti } \\
\text { females }\end{array}$ & IFMA \\
\hline \multirow[t]{19}{*}{2010} & 1 & 2 & 0 & 0.00 \\
\hline & 2 & 2 & 0 & 0.00 \\
\hline & 3 & 2 & 0 & 0.00 \\
\hline & 4 & 1 & 0 & 0.00 \\
\hline & 5 & 2 & 0 & 0.00 \\
\hline & 6 & 2 & 0 & 0.00 \\
\hline & 7 & 2 & 0 & 0.50 \\
\hline & 8 & 2 & 0 & 0.00 \\
\hline & 9 & 2 & 0 & 0.00 \\
\hline & 10 & 1 & 0 & 0.00 \\
\hline & 11 & 1 & 2 & 2.00 \\
\hline & 12 & 2 & 0 & 0.00 \\
\hline & 13 & 1 & 0 & 0.00 \\
\hline & 14 & 2 & 0 & 0.00 \\
\hline & 15 & 2 & 0 & 0.00 \\
\hline & 16 & 2 & 0 & 0.00 \\
\hline & 17 & 2 & 0 & 0.00 \\
\hline & 18 & 2 & 0 & 0.00 \\
\hline & 19 & 0 & 0 & 0.00 \\
\hline \multirow[t]{19}{*}{2011} & 1 & 50 & 47 & 0.94 \\
\hline & 2 & 50 & 3 & 0.06 \\
\hline & 3 & 50 & 0 & 0.00 \\
\hline & 4 & 50 & 0 & 0.00 \\
\hline & 5 & 50 & 2 & 0.04 \\
\hline & 6 & 50 & 2 & 0.04 \\
\hline & 7 & 50 & 2 & 0.04 \\
\hline & 8 & 50 & 1 & 0.02 \\
\hline & 9 & 50 & 0 & 0.00 \\
\hline & 10 & 50 & 4 & 0.08 \\
\hline & 11 & 50 & 2 & 0.04 \\
\hline & 12 & 50 & 2 & 0.04 \\
\hline & 13 & 50 & 0 & 0.00 \\
\hline & 14 & 50 & 0 & 0.00 \\
\hline & 15 & 50 & 3 & 0.06 \\
\hline & 16 & 50 & 0 & 0.00 \\
\hline & 17 & 50 & 1 & 0.02 \\
\hline & 18 & 50 & 3 & 0.06 \\
\hline & 19 & 37 & 1 & 0.02 \\
\hline \multirow[t]{2}{*}{2012} & 1 & 49 & 43 & 0.87 \\
\hline & 2 & 49 & 4 & 0.08 \\
\hline
\end{tabular}

\begin{tabular}{|c|c|c|c|c|}
\hline Years & IDs & $\begin{array}{l}\text { Number } \\
\text { of traps } \\
\text { inspected }\end{array}$ & $\begin{array}{l}\text { Number of } \\
\text { A. aegypti } \\
\text { females }\end{array}$ & IFMA \\
\hline \multirow[t]{17}{*}{2012} & 3 & 48 & 0 & 0.00 \\
\hline & 4 & 49 & 3 & 0.06 \\
\hline & 5 & 49 & 2 & 0.04 \\
\hline & 6 & 49 & 2 & 0.04 \\
\hline & 7 & 49 & 0 & 0.00 \\
\hline & 8 & 49 & 3 & 0.06 \\
\hline & 9 & 48 & 1 & 0.02 \\
\hline & 10 & 49 & 3 & 0.06 \\
\hline & 11 & 48 & 2 & 0.04 \\
\hline & 12 & 47 & 1 & 0.02 \\
\hline & 13 & 49 & 0 & 0.00 \\
\hline & 14 & 49 & 0 & 0.00 \\
\hline & 15 & 49 & 1 & 0.02 \\
\hline & 16 & 48 & 0 & 0.00 \\
\hline & 17 & 49 & 2 & 0.04 \\
\hline & 18 & 48 & 1 & 0.02 \\
\hline & 19 & 49 & 2 & 0.04 \\
\hline \multirow{19}{*}{2013} & 1 & 16 & 15 & 0.93 \\
\hline & 2 & 16 & 1 & 0.06 \\
\hline & 3 & 16 & 0 & 0.00 \\
\hline & 4 & 16 & 0 & 0.00 \\
\hline & 5 & 16 & 0 & 0.00 \\
\hline & 6 & 16 & 1 & 0.06 \\
\hline & 7 & 16 & 0 & 0.00 \\
\hline & 8 & 16 & 0 & 0.00 \\
\hline & 9 & 16 & 1 & 0.06 \\
\hline & 10 & 16 & 0 & 0.00 \\
\hline & 11 & 16 & 0 & 0.00 \\
\hline & 12 & 16 & 0 & 0.00 \\
\hline & 13 & 16 & 0 & 0.00 \\
\hline & 14 & 16 & 0 & 0.00 \\
\hline & 15 & 16 & 0 & 0.00 \\
\hline & 16 & 16 & 0 & 0.00 \\
\hline & 17 & 16 & 0 & 0.00 \\
\hline & 18 & 16 & 0 & 0.00 \\
\hline & 19 & 16 & 0 & 0.00 \\
\hline Total & & 2,197 & 163 & $0.07^{\star}$ \\
\hline
\end{tabular}


Table 2 - Total number of collected mosquitoes during the period from December 2010 to 2013, in the studied locations of the Seropédica municipality, RJ, with the determination of species and sex

\begin{tabular}{|c|c|c|c|c|c|c|}
\hline \multirow{2}{*}{ Species } & \multirow{2}{*}{ Sex } & \multicolumn{4}{|c|}{ Years } & \multirow{2}{*}{ Total } \\
\hline & & 2010 & 2011 & 2012 & 2013 & \\
\hline \multirow{2}{*}{ Aedes sp. } & Male & 2 & 0 & 0 & 0 & 2 \\
\hline & Female & 1 & 25 & 7 & 3 & 36 \\
\hline \multirow{2}{*}{ Aedes aegypti } & Male & 0 & 3 & 2 & 0 & 5 \\
\hline & Female & 2 & 73 & 70 & 18 & 163 \\
\hline \multirow{2}{*}{ Aedes albopictus } & Male & 0 & 11 & 5 & 14 & 30 \\
\hline & Female & 11 & 233 & 335 & 126 & 705 \\
\hline \multirow{2}{*}{ Culex sp. } & Male & 9 & 180 & 154 & 47 & 390 \\
\hline & Female & 23 & 323 & 443 & 123 & 912 \\
\hline Total & & 48 & 848 & 1,016 & 331 & 2,243 \\
\hline
\end{tabular}

reached for transmission of the disease in the epidemiological weeks $50(0.47)$ and $13(0.32)$, respectively. The year of 2012 was that in which the moderate level was more present sometimes coming close to the alert level (Figure 3 ).

By the location where the traps were deployed, the ID1 (Instituto de Veterinária - UFRRJ) was the one which reached the critical level of the disease (0.90), with the sum of the number of females of A. aegypti found throughout the research period. All the other IDs remained within the range stipulated as satisfactory. The IDs 3, 13, 14 and 16 were those with negative indices of disease transmission. The IMFA calculated from the total number of female A. aegypti by the total number of traps inspected, during the entire research, found the value of 0.07 , classified as satisfactory (Table 1, Figure 3 ).

The IM-Virus was conducted only in the epidemiological weeks of the year 2012 and did not detect the presence of dengue serotypes in mosquitoes collected by the municipality selected IDs.

The statistical analysis confirmed a strong association $(r=0.7160)$ between the number of females of $A$. aegypti and average temperatures from weeks 14 to 26 corresponding to the months of April, May and June (autumn). Regarding the association between the number of females of $A$. aegypti and the average rainfall, a moderate association $(r=0.4043)$ was found in weeks 40-52, for the months of October, November and December (spring) (Figure 4).

\section{DISCUSSION}

During the entire research, the ID1 (Instituto de Veterinária - UFRRJ) had the largest number of females of A. aegypti, reaching an IFMA considered as critical (0.90), considering the risk of disease transmission. The ID1 is the only one surrounded by a remaining forest with lakes.
This insect is primarily a forest species, occurring on its edges, moving into human households and with preference for humidity; its breeding place consists predominantly of places with standing water. Indeed, the environment itself makes ID1 a favorable area for proliferation of the mosquito, something that does not happen with the other IDs ${ }^{12,17-19}$.

The IDs 3, 13 and 14 are animal breeding and reproduction areas, which may explain the negative ratio of mosquito presence in the research period, given the frequency in use of insecticides in the environment, using for baths and sprinkling ${ }^{20,21}$. The ID16, the University Hall, is the starting point of all anti-vector and pathology campaign, thus becoming an excellent inspection place.

The low number of females of A. aegytpi studied in epidemiological weeks 28 to 34, 2011 (July and August), and 19 to 30, 2012 (from May to July), can be explained by the beginning of a drop in temperature and rainfall occurred in the town, representing the autumn and winter seasons. Ribeiro et al. ${ }^{22}$, working on the association between dengue incidence and climate variables, noted that high temperature and rainfall contribute to a higher density of mosquitoes and disease occurrence. Costa et al. ${ }^{23}$ and Souza et al. ${ }^{24}$ evidenced a large incidence of the mosquito in high temperature and rainy seasons. All these studies, either by the value observed during the epidemiological weeks, either by the statistical analysis results, proved that there is a weak correlation between lower temperatures/rainfall and the number of $A$. aegypti in the environment, the opposite of what really happens in the warmer months of the year.

By calculating the average IMFA of the studied IDs $(0.07)$, counting all the years, it can be said that the chosen locations did not pose a risk of disease transmission to local passers-by during the whole research. That goes against what was observed in the ID1 (Instituto de Veterinária UFRRJ). The ID1 has a high rate of the occurrence of the 

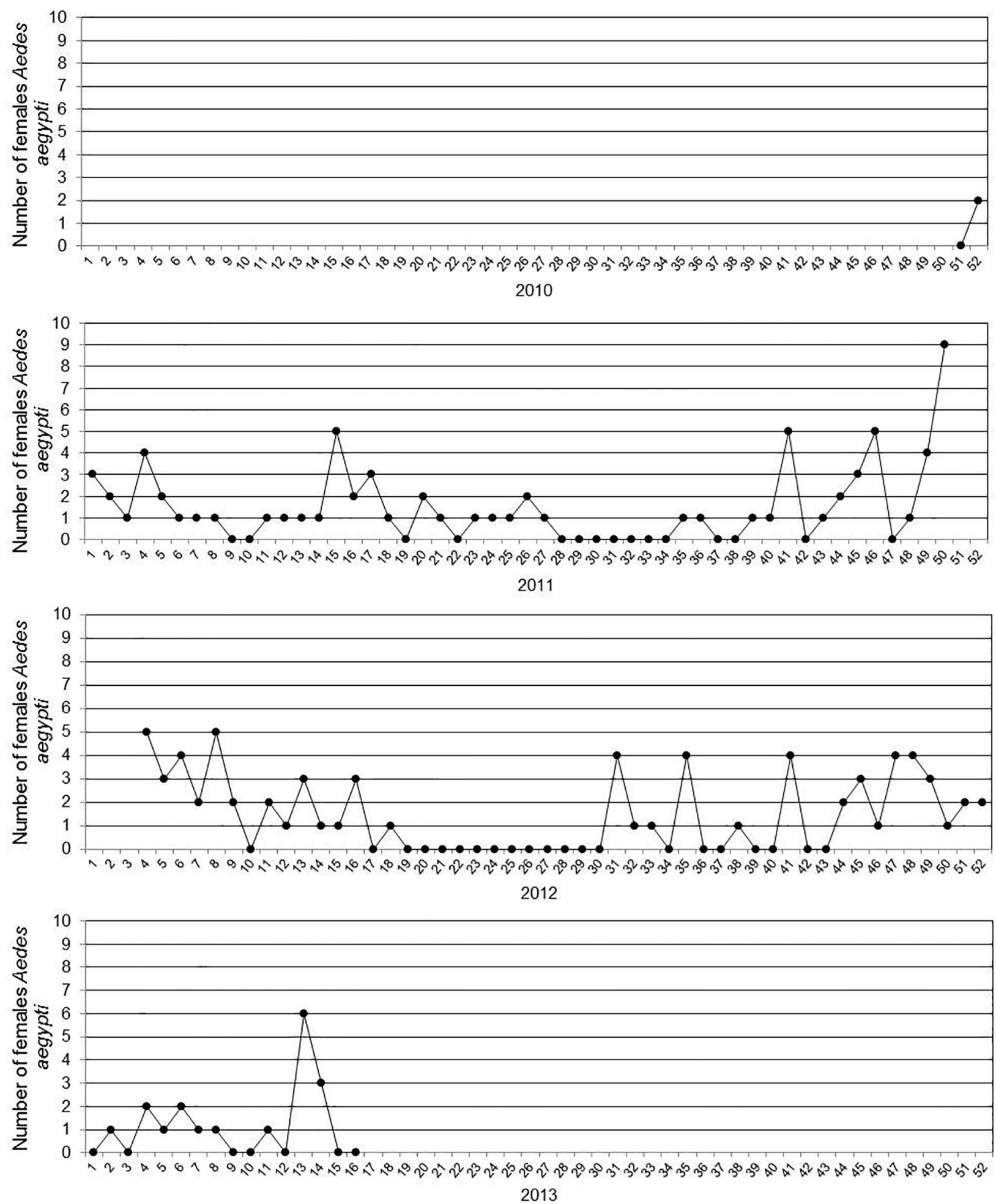

Figure 2 - Number of collected females of Aedes aegypti, by epidemiologic week, during the period from December 2010 to April 2013, in 19 locations from the Seropédica municipality, RJ

disease. This ID is considered an imminent danger zone, and authorities should take necessary measures to reverse this situation.

The data analysis does not show a significant increase in the number of females of $A$. aegypti during the entire research, however, preventive measures are necessary in order to maintain or reduce this number. The data obtained from the research demonstrated the importance of the tools used in the city and, thus, can locate and target the necessary measures to prevent possible cases of the disease. 

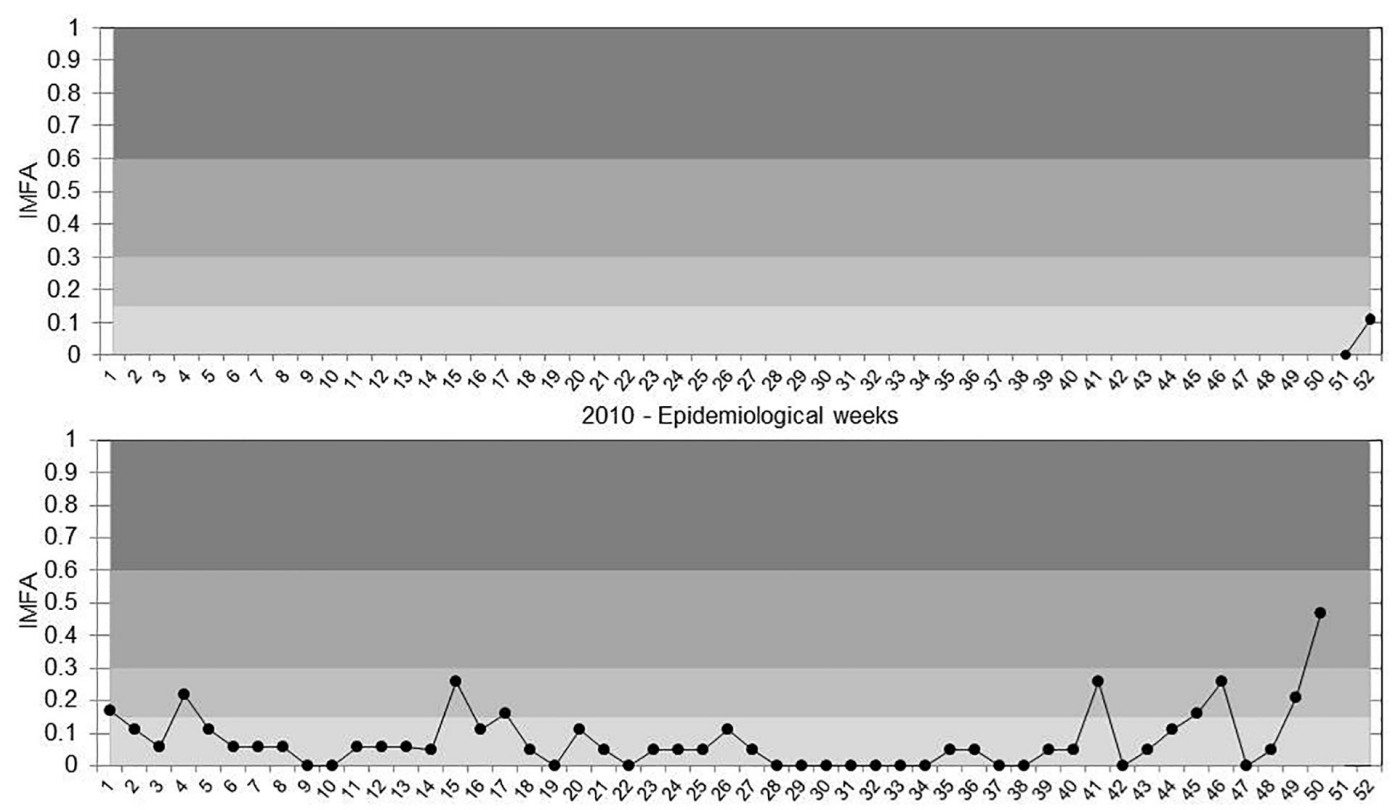

2011 - Epidemiological weeks

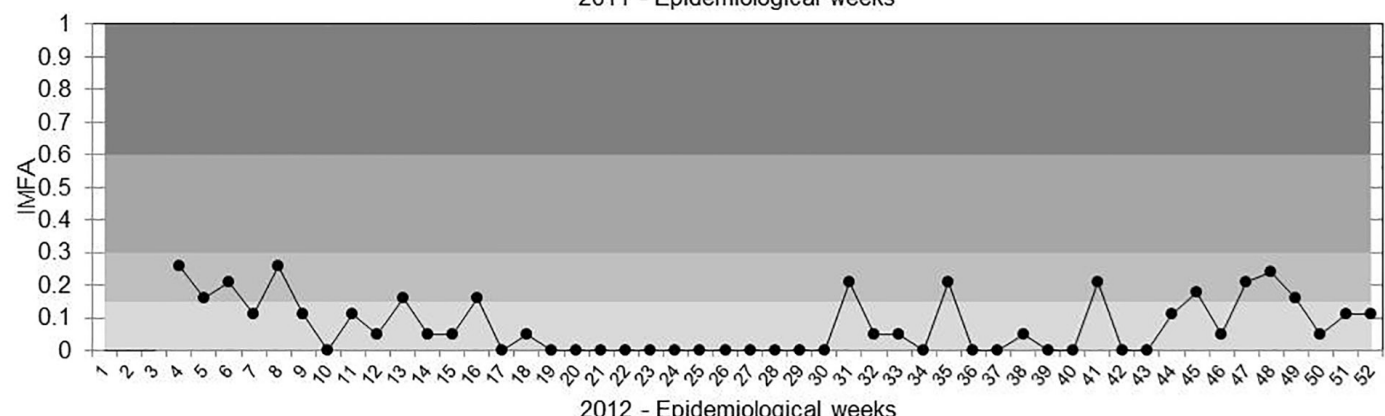

2012 - Epidemiological weeks

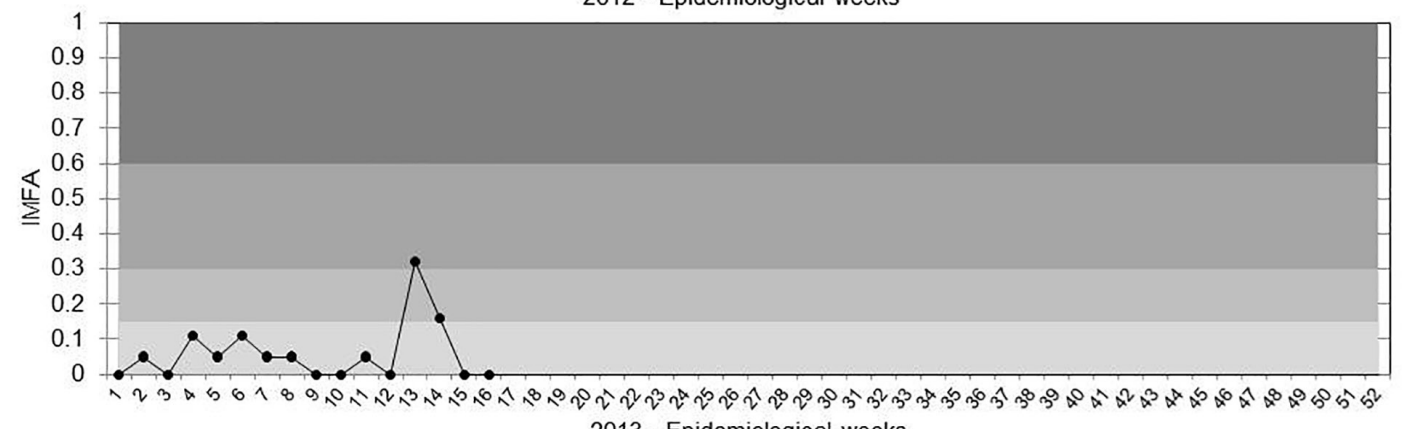

2013 - Epidemiological weeks

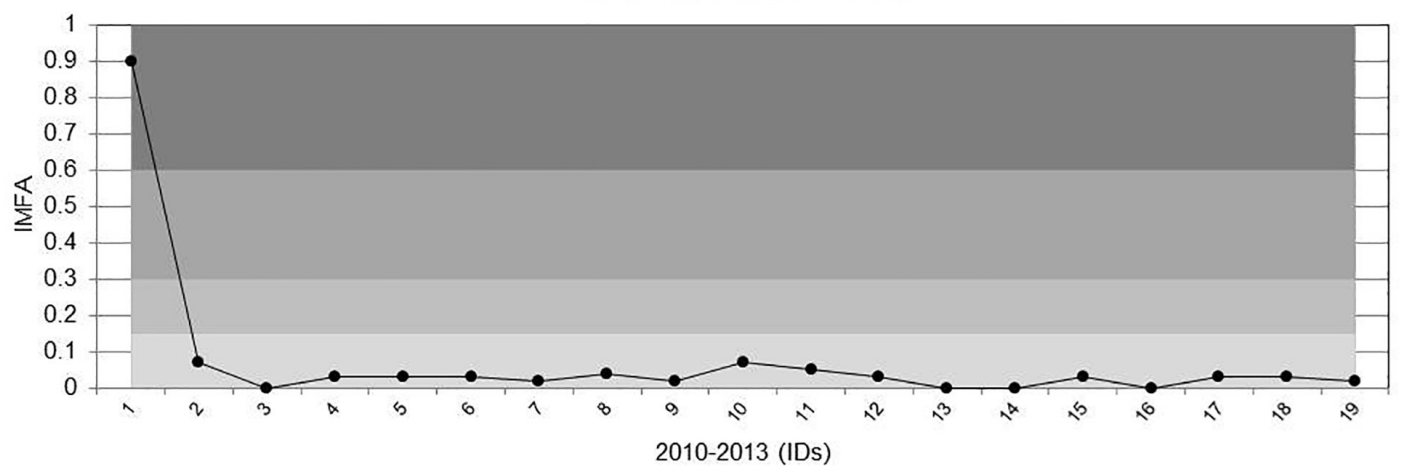

घritical $\quad$ Alert $\quad$ Moderated $\quad$ Satisfactory

Figure 3 - Average index of females of Aedes aegypti (IFMA), calculated by epidemiological week and the inspected trap locations (IDs), from December 2010 to April 2013, in the Seropédica municipality, RJ, indicating the transmission risk levels of the disease 

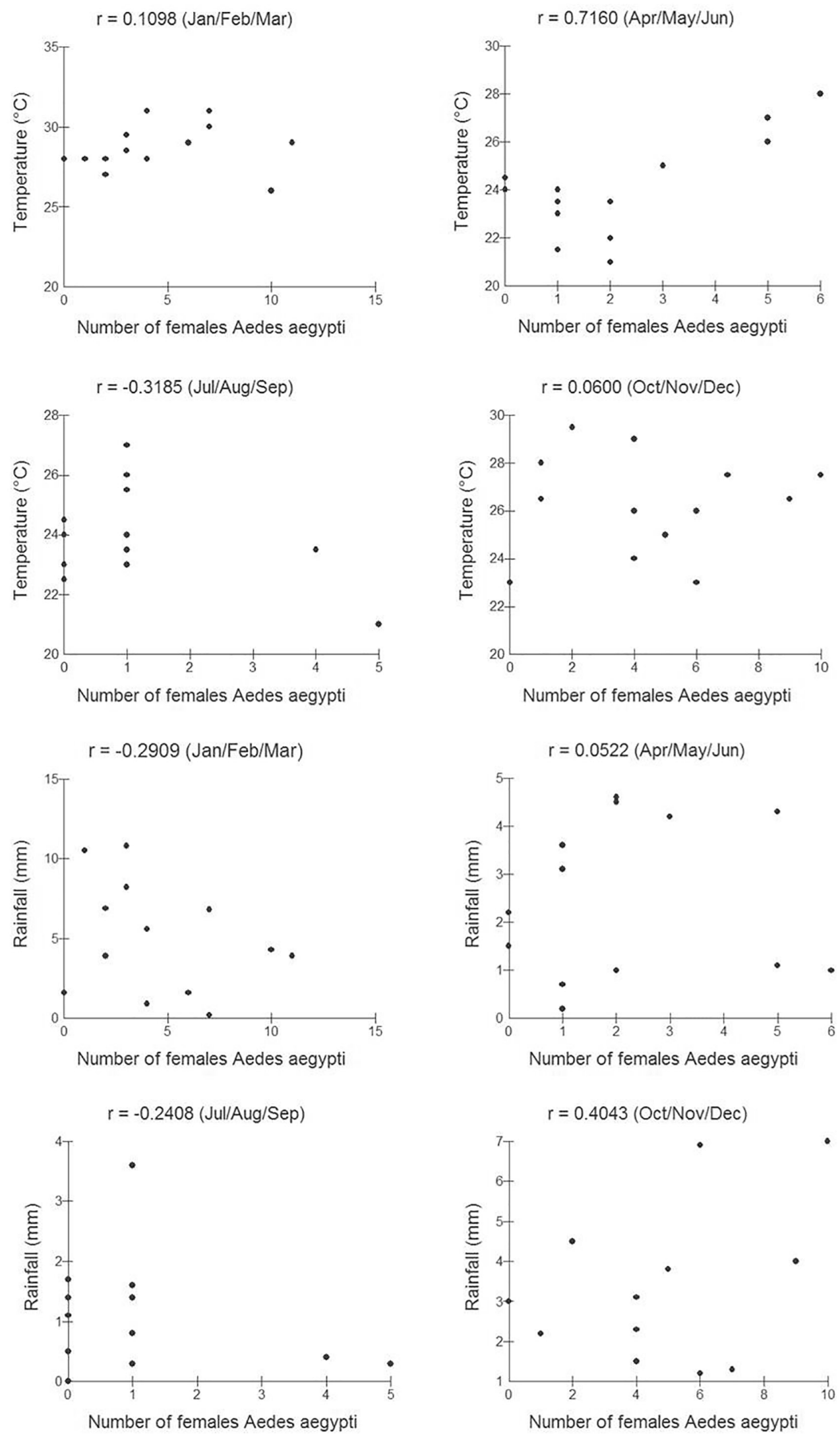

Figure 4 - Scatter plot of the number of females of Aedes aegypti with average environmental temperature and average rainfall, in the 52 weeks of the research period (2010-2013), in the Seropédica municipality, RJ: summer (Jan/Feb/Mar) - weeks 1 to 13, autumn (Apr/May/Jun) - weeks 14 to 26, winter (Jul/Aug/Sep) - weeks 27-39 and spring (Oct/Nov/Dec) - weeks 40-52 
The absence of dengue virus in selected locations can be evaluated as a positive point; however, the presence of the mosquito does not rule out the possibility of future contamination of passers-by. The municipality is basically an university city, with much of its population coming from other municipalities of the Rio de Janeiro State, as well as from other states; this means that people infected with the virus in their city of origin, and still in the incubation period of the disease, can act as a carrier and source of the virus favoring its circulation in the city, and together with the vector, will cause other dengue cases. Prophylactic measures should always be taken against $A$. aegypti breeding locations thus preventing their proliferation and the spread of this disease.

\section{CONFLICT OF INTERESTS}

The authors declare that there is no conflict of interest.

\section{REFERENCES}

1. Brasil. Ministério da Saúde. Secretaria de Vigilância em Saúde. Departamento de Vigilância Epidemiológica. Guia de vigilância epidemiológica. $6^{\text {a }}$ ed. Brasília: Ministério da Saúde; 2005.

2. Joia LC, Rego EC, Barbosa MA, Pinto SM. Nível de informação e prevenção da dengue entre os moradores de Barreiras/BA. Rev APS. 2012;15:42-8.

3. World Health Organization. Dengue and severe dengue. Geneva: WHO; 2015 [cited 2015 Aug 16]. Available from: http://www. who.int/mediacentre/factsheets/fs117/en/

4. Brasil. Ministério da Saúde. Novo balanço registra queda de $68 \%$ nos casos de dengue. Brasília: Ministério da Saúde; 2015 [cited 2015 Nov 12]. Available from: http://portalsaude.saude.gov.br/index. php/o-ministerio/principal/secretarias/svs/noticias-svs/18031ministerio-da-saude-divulga-novo-balanco-de-dengue

5. Rio de Janeiro. Secretaria de Saúde. Gerência de Doenças Transmitidas por Vetores e Zoonoses. Dengue: cenário epidemiológico e perspectiva para o ano de 2016. Bol Epidemiol. 2015;7:1-7.

6. Rio de Janeiro. Secretaria de Saúde. Doenças e agravos de notificação. Rio de Janeiro: Secretaria de Saúde; 2016. [cited 2017 May 24]. Available from: http://www.saude.rj.gov.br/ informacao-sus/indicadores/2017/02/doencas-e-agravos-denotificacao

7. Carvalho DF, Silva LD, Guerra JG, Cruz FA, Souza AP. Instalação, calibração e funcionamento de um lisímetro de pesagem. Eng Agríc. 2007;27:363-72.

8. Instituto Brasileiro de Geografia e Estatística. Cidades. Brasília: IBGE; 2015. [cited 2015 Aug 25]. Available from: http:// cidades.ibge.gov.br/xtras/home.php
9. Ferreira I, Ventura PE, Luz HR. Aves no Campus da Universidade Federal Rural do Rio de Janeiro. Rio de Janeiro: Editora da Universidade Federal Rural do Rio de Janeiro; 2010.

10. Pepin KM, Marques-Toledo C, Scherer L, Morais MM, Ellis B, Eiras AE. Cost-effectiveness of novel system of mosquito surveillance and control, Brazil. Emerg Infect Dis. 2013;19:542-50.

11. Ecovec. Belo Horizonte: Ecovec; 2015 [cited 2015 Sep 18]. Available from: http://www.ecovec.com

12. Consoli RA, Oliveira RL. Principais mosquitos de importância sanitária no Brasil. Rio de Janeiro: FIOCRUZ; 1994.

13. Reinert JF. New classification for the composite genus Aedes (Diptera: Culicidae: Aedini), elevation of subgenus Ochlerotatus to generic rank, reclassification of the other subgenera. and notes on certain subgenera and species. J Am Mosq Control Assoc. 2000;16:175-88.

14. Brasil. Instituto Nacional de Meteorologia. Estações automáticas: gráficos. Brasília: Ministério da Agricultura, Pecuária e Abastecimento; 2015 [cited 2015 Apr 12]. Available from: http://www.inmet.gov.br/portal/index.php?r=home/ page\&page=rede_estacoes_auto_graf

15. Statistical Package for the Social Sciences: version 19.0. Chicago: SPSS Inc; 2010.

16. Callegari-Jacques SM. Bioestatística: princípios e aplicações. Porto Alegre: Artmed; 2003.

17. Taipe-Lagos CB, Natal D. Abundância de culicídeos em área metropolitana preservada e suas implicações epidemiológicas. Rev Saúde Públ. 2003;37:275-9.

18. Lourenço-de-Oliveira R, Castro MG, Braks MA, Lounibos LP. The invasion of urban forest by dengue vectors in Rio de Janeiro. J Vector Ecol. 2004;29:94-100.

19. Marcondes CB, Tauil PL. Dengue silvestre: devemos nos preocupar? Rev Soc Bras Med Trop. 2011;44:263-4.

20. Braga IA, Valle D. Aedes aegypti: inseticidas, mecanismos de ação e resistência. Epidemiol Serv Saude. 2007;16:279-93.

21. Andrighetti MT, Macoris ML, Takaku L, Galvani KC, Cardoso RP, Scandar SS, et al. Avaliação do efeito do inseticida malathion aplicado sob a forma de ultra baixo volume com equipamentos portátil e pesado sobre Aedes aegypti (Diptera: Culicidae). Rev Patol Trop. 2013;42:81-95.

22. Ribeiro AF, Marques GR, Voltolini JC, Condino ML. Associação entre incidência de dengue e variáveis climáticas. Rev Saúde Públ. 2006;40:671-6.

23. Costa FS, Silva JJ, Souza CM, Mendes J. Dinâmica populacional de Aedes aegypti (L) em área urbana de alta incidência de dengue. Rev Soc Bras Med Trop. 2008;41:309-12.

24. Souza SS, Silva IG, Silva HH. Associação entre incidência de dengue, pluviosidade e densidade larvária de Aedes aegypti, no Estado de Goiás. Rev Soc Bras Med Trop. 2010;43:152-5. 